\title{
SOSIALISASI PEMBERIAN MINUMAN KURMA TERHADAP PENINGKATAN KADAR HEMOGLOBIN PADA IBU HAMIL ANEMIA RUMAH SAKIT GRANDMED LUBUK PAKAM
}

\author{
Wira Maria Ginting ${ }^{1 *}$, Raini Panjaitan' ${ }^{1}$, Delita Br Panjaitan ${ }^{1}$, Jelita Manurung ${ }^{1}$ \\ ${ }^{1}$ Program Studi Gizi, Institut Kesehatan Medistra Lubuk Pakam \\ JIn. Sudirman No.38 Lubuk Pakam, Kabupaten Deli Serdang, \\ Sumatera Utara - Indonesia \\ *email korespondensi author: wiramariag@gmail.com
}

DOI $10.35451 /$ jpk.v1i1.735

\begin{abstract}
Abstrak
Kejadian anemia penyebab utama pendarahan. Anemia merupakan suatu masalah kesehatan akibat defisiensi mineral zat besi (Fe). Penyakit ini merupakan salah satu penyakit yang berhubungan dengan ibu hamil yang dapat mengganggu kesehatan ibu dan janin. Pelaksanaan sosialisasi pengabdian masyarakat ini telah dilaksanakan selama empat hari di Rumah Sakit Grandmed Lubuk Pakam. Tujuan kegiatan sosialisasi ini adalah untuk meningkatkan kadar hemoglobin melalui pemberian minuman kurma. Ibu hamil diberikan 1 gelas minuman kurma selama empat hari. Pada hari pertama tim pelaksana melakukan edukasi dan diskusi tentang manfaat kurma untuk meningkatkan kadar Hb. Berdasarkan kegiatan sosialisasi ini diperoleh para peserta mendapat informasi dan pengetahuan tentang anemia dan pemanfaatan minuman kurma terhadap peningkatan kadar $\mathrm{Hb}$. Dari hasil sosialisasi selama empat hari bahwa setelah pemberian minuman kurma dapat meningkatkan kadar $\mathrm{Hb}$ ibu hamil anemia dengan rata-rata 0,24 mg/dl dari 18 peserta.
\end{abstract}

Kata kunci : kadar hemoglobin, anemia, kurma

\begin{abstract}
The incidence of anemia is the main cause of bleeding. Anemia is a health problem due to deficiency of the mineral iron (Fe). This disease is one of the diseases associated with pregnant women that can interfere with the health of the mother and fetus. The implementation of this community service socialization has been carried out for four days at Grandmed Lubuk Pakam Hospital. The purpose of this socialization activity is to increase hemoglobin levels through the provision of date drinks. Pregnant women are given 1 glass of date drink for four days. On the first day, the implementing team conducted education and discussion about the benefits of dates to increase $\mathrm{Hb}$ levels. Based on this socialization activity, participants obtained information and knowledge about anemia and the use of date drinks to increase $\mathrm{Hb}$ levels. From the results of socialization for four days that after giving dates drinks can increase the $\mathrm{Hb}$ level of anemic pregnant women by an average of $0.24 \mathrm{mg} / \mathrm{dl}$ from 18 participants.
\end{abstract}

Keywords: Hemoglobin levels, anemia, dates 
Received: 09 June 2021 ::Accepted: 23 June 2021 :: Published: 30 June 2021

\section{Pendahuluan}

Kejadian AKI (angka kematian ibu) adalah sebagai indikator tingkat kesehatan wanita. Saat ini tingginya kejadian AKI di Indonesia menjadi masalah prioritas di bidang kesehatan wanita, yaitu tingkat kesehatan di lingkungan masyarakat, yang menggambarkan tingkat kesejahteraan dan kualitas pelayanan kesehatan di masyarakat. Salah satu faktor risiko tingginya kejadian AKI dalam melahirkan adalah anemia pada masa kehamilan. Kejadian Anemia pada ibu hamil merupakan penyebab utama terjadinya perdarahan yang merupakan pemicu kematian pada ibu di Indonesia. Hasil penelitian evidence base epidemiologi, bahwa penderita anemia atau defisiensi zat besi pada ibu hamil di Indonesia menunjukkan sebanyak $70 \%$ mengalami kejadian AKI ibu hamil dan sebanyak $19,7 \%$ ibu hamil yang tidak menderita anemia (Amiruddin, 2014).

Kejadian Anemia penyebab utama pendarahan. Anemia merupakan suatu masalah kesehatan akibat defisiensi mineral zat besi (Fe). Penyakit ini merupakan salah satu penyakit yang berhubungan dengan ibu hamil yang dapat mengganggu kesehatan ibu dan janin (Anggraini dkk, 2018). Kejadian anemia pada ibu hamil adalah kondisi dimana kadar hemoglobin $(\mathrm{Hb})$ di dalam darah kurang dari $11 \quad$ gr\% yang mengakibatkan kapasitas daya angkut oksigen $\left(\mathrm{O}_{2}\right)$ untuk kebutuhan organorgan ibu dan janin menjadi berkurang. Ibu hamil yang mengalami anemia pada trimester I dan III jumlah kadar $\mathrm{Hb}$ di bawah $11,0 \mathrm{~g} \%$. Prevelensi dunia pada anemia ibu hamil sebesar $41,2 \%$ sedangkan prevelensi anemia ibu hamil di Indonesia sebesar 37,1\% (WHO, 2012).Anemia pada ibu hamil dapat menghambat pertumbuhan sel janin pada otak janin (Fardilah dkk 2020). Disamping itu, ibu yang mengalami anemia memiliki risiko terhadap abortus, berat bayi lahir rendah, premature hingga kematian pada bayi dan ibu. Salah satu cara mengatasi dan mencegah masalah anemia pada masa kehamilan mengkonsumsi makanan yang tinggi mengandung zat besi yaitu kurma. Buah kurma mengandung energi yang tinggi yang memiliki kandungan karbohidrat, triptofan, vitamin C, B6, serat, besi, zink, fosfor dan mineral lainnya (Widowati dkk 2019).

Berdasarkan informasi di atas maka perlu dilaksanakan sosialisasi tentang kejadian anemia pada ibu hamil dan cara meningkatkan kadar $\mathrm{Hb}$ dan kreasi pengembangan olahan kurma sebagai cara penanggulangan kejadian anemia bagi ibu hamil. Pelaksanaan pengabdian masyarakat ini bertujuan untuk meningkatkan kadar $\mathrm{Hb}$ ibu hamil anemia melalui pemberian minuman kurma di Rumah Sakit Grandmed Lubuk Pakam.

\section{Metode}

Metode pelaksanaan sosialisasi diawali dengan pendataan jumlah pasien ibu hamil anemia berserta pengukuran $\mathrm{Hb}$ awal peserta di Rumah Sakit Grandmed Lubuk Pakam menggunakan alat Accu Chek Hemoglobin. Selanjutnya dilaksanakan penyuluhan melalui ceramah dan diskusi tentang manfaat konsumsi buah kurma untuk meningkatkan kadar hemoglobin beserta pembagian leaflet tentang informasi kurma dan anemia. Pada hari pertama hingga hari ke sepuluh dilakukan pemberian minuman kurma dan pada hari terakhir dilakukan penggukuran kadar $\mathrm{Hb}$ setelah diberi perlakuan. Pada saat pelaksanaan kegiatan dilakukan diskusi dan tanya jawab. 
Received: 09 June 2021 ::Accepted: 23 June 2021 :: Published: 30 June 2021

\section{Hasil dan Pembahasan}

Pelaksanaan kegiatan sosialisasi pengabdian masyarakat pemberian kurma kepada ibu hamil anemia di Rumah Sakit Grandmed Lubuk Pakam. Dilaksanakan pada tanggal 29 April-8 Mei 2021 bertempat di Rumah Sakit Grandmed Lubuk Pakam, Jalan Raya Medan-Lubuk Pakam Km 25 No. 66 Lubuk Pakam kabupaten Deli Serdang, dengan jumlah peserta kegiatan sebanyak 18 orang ibu hamil yang menderita anemia. Sosialisasi ini dilaksanakan dengan menerapkan protokol kesehatan.

Kegiatan ini berlangsung selama 4 hari. Pada hari pertama tim pelaksana melakukan penyuluhan tentang anemia, resiko anemia pada ibu hamil, manfaat konsumsi kurma pada penderita anemia yang disampaikan melalui ceramah dan diskusi. Pada hari kedua dan ketiga pemberian kurma. Berikut adalah karakteristik ibu hamil anemia pada kegiatan sosialisai pengabdian kepada masyarakat.

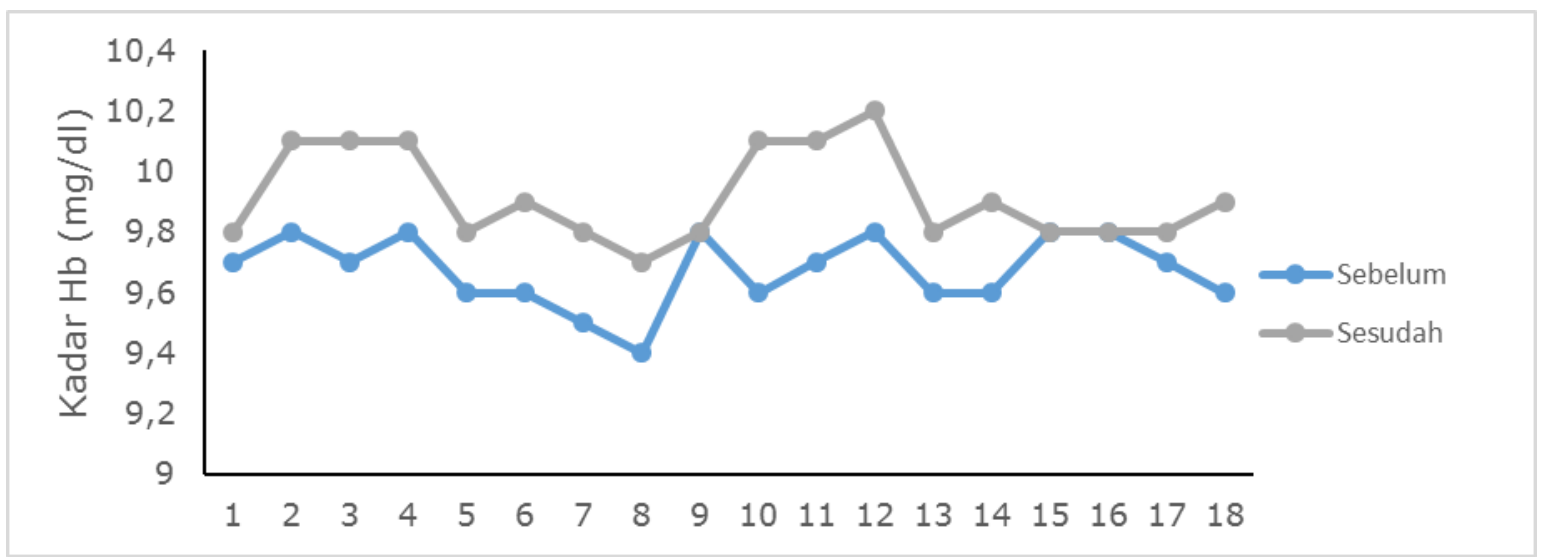

Gambar 1. Rata-Rata Hasil Pengukuran Kadar Hb (mg/dl) Sebelum dan Sesudah Pemberian Minuman Kurma Terhadap Ibu Hamil Anemia

Hasil kegiatan intervensi terhadap peningkatan kadar $\mathrm{Hb} 18$ ibu hamil anemia setelah pemberian minuman kurma bahwa mayoritas kadar $\mathrm{Hb}$ ibu mampu meningkat dari kadar $\mathrm{Hb}$ sebelumnya. Berdasarkan Gambar 2. bahwa rata-rata peningkatan kadar $\mathrm{Hb}$ sekitar 0,24 $\mathrm{mg} / \mathrm{dl}$ selama 4 hari pemberian minuman kurma. Berdasarkan data yang diperoleh sebelum pemberian minuman kurma bahwa kadar $\mathrm{Hb}$ ibu hamil yang paling rendah adalah 9,4 $\mathrm{mg} / \mathrm{dl}$ dan nilai $\mathrm{Hb}$ paling tinggi adalah $9,8 \mathrm{mg} / \mathrm{dl}$. Sedangkan hasil rata-rata nilai kadar $\mathrm{Hb}$ ibu hamil anemia setelah dilakukan intervensi pemberian minuman kurma bahwa kadar $\mathrm{Hb}$ ibu hamil yang paling rendah adalah 9,7 $\mathrm{mg} / \mathrm{dl}$ dan nilai $\mathrm{Hb}$ paling tinggi adalah $10,2 \mathrm{mg} / \mathrm{dl}$.

Menurut Sugita dan Kuswati (2020) bahwa pengaruh pemberian konsumsi buah kurma mampu meningkatkan kada hemoglobin pada ibu hamil trimester 3 yang menderita anemia. Hal ini menunjukkan bahwa kandungan sari kurma secara tidak langsung mampu meningkatkan trombosit dan zat besi yang esensial bagi pembentukan hemoglobin.

\section{Kesimpulan}

Pelaksanan kegiatan sosialisasi pemberian minuman kurma ini telah berjalan dengan baik, baik tim pelaksana, mitra kegiatan dan para 
peserta kegitan. Setelah mendapatkan sosialisasi para peserta mendapat informasi dan pengetahuan tentang anemia, dan pemanfaatan minuman kurma terhadap peningkatan kadar $\mathrm{Hb}$. Dari hasil sosialisasi selama empat hari bahwa setelah pemberian minuman kurma dapat meningkatkan kadar $\mathrm{Hb}$ ibu hamil anemia dengan rata-rata 0,24 mg/dl dari 18 peserta.

\section{Ucapan Terima Kasih}

Penulis mengucapkan terima kasih kepada Rumah Sakit Grandmed Lubuk Pakam yang telah membantu penulis dalam kegiatan sosialisasi bagi pasien ibu nifas, beserta tim Prodi Gizi, terima kasih atas segala kerjasamanya.

\section{Daftar Pustaka}

Amiruddin. (2014). Faktor-Faktor Yang Mempengaruhi Kepatuhan Ibu Hamil Dalam Mengkonsumsi Tablet Besi Di Desa Sokaraja Tengah, Kecamatan Sokaraja, Kabupaten Banyumas. JKS;3(3).

Anggraini, D, D., Purnomo, W., \& Trijanto, B. (2018). Interaksi Ibu Hamil Dengan Tenaga Kesehatan Dan Pengaruhnya Terhadap Kepatuhan Ibu Hamil Mengonsumsi Tablet Besi ( $\mathrm{Fe}$ ) Dan Anemia Di Puskesmas Kota Wilayah Selatan Kota Kediri. Buletin Penelitian Sistem Kesehatan, 21(2), 82-89.

Fardillah N., Kridawati A., Ulfa L. (2020). Pengaruh Penambahan Sari Kurma Terhadap Kadar Heboglobin Ibu Hamil Anemia Di Klinik Fistha Nanda Tahun 2020. Jurnal Untuk Masyarakat Sehat (Jukmas), 4(2), 201-215.

Widowati R., Kundaryanti R., Lestari PP. Pengaruh Pemberian Sari Kurma Terhadap Peningkatan Kadar Hemoglobin Ibu Hamil. Jurnal Al-Azhar Indonesia
Seri Sains Dan Teknologi, 5(2), 6065.

Sugita \& Kuswati. (2020). Pengaruh Konsumsi Buah Kurma Terhadap Peningkatan Kadar Hemoglobin Pada Ibu Hamil Trimester Iii. Jurnal Kebidanan Dan Kesehatan Tradisional, 5 (1), 58-66

World Health Organization (WHO). (2012). Haemoglobin conentrations for the diagnosis of anemia and assessment of severity, vitamin, mineral nutrition information system. https://www.who.int/vmnis/indica tors/haemoglobin/en/. 